\title{
O QUE APRENDI CONVIVENDO COM CRIANÇAS ÓRFÃS
}

\author{
Miriam Lêda de Mello e Santos *
}

SANTOS, M. L. de $M$. e. O que aprendi convivendo com crianças órfãs. Rev. Esc. Enf. USP, São Paulo, 16(1):103-196, 1982.

A autora apresenta um relato de experiências que teve durante o estágio em uma orfanato, ressaltando alguns aspectos significativos para sua aprendizagem. Conclui que as crianças, apesar de órfãs, necessitam de alguém que receba o muito amor que têm para dar.

Durante o curso de Enfermagem Pediátrica, interessei-me por crianças amendrontadas, agressivas, caladas e por aquelas que eram espancadas em casa. Desejava entender o que se passava em sua mente, como elas percebiam o que viam, como e porque sofriam. Eu sempre me lembrava dos órfãos.

Como são as crianças de um orfanato? O que pensam? São todas agressivas? Sabem amar sem jamais terem sido amadas? Poderei fazer alguma coisa? Quanto vale uma criança? Com todas estas perguntas em minha mente, comecei a interessar-me por órfãos. Eu queria saber como são, na verdade, e o que pode ser feito por eles.

As crianças sofrem muito na hospitalização quando são separadas da mãe; é como se perdessem parte de si. A mãe é a ponte que liga a criança ao mundo que a cerca, é o ponto de partida para conhecer o ambiente. Os pais dão segurança, são o modelo e, como diz FRAIBERG ", representam "necessidades básicas atendidas". A criança quer e precisa ser percebida, notada, apreciada, o que é importante na formação da sua auto-imagem, auto-confiança, auto-conceito. Eu pergunto: "E os órfãos?"

Durante todo o curso eu me detive a estudar o comportamento emocional dos pequenos. Tudo que via e aprendia tentava, mentalmente, transferir para os órfãos. Mas, só isso não foi suficiente. Para que eu aprendesse realmente, foi preciso que me colocasse entre eles, que os sentisse, que convivesse com eles. Isso foi possivel porque uma docente obteve permissão para eu estagiar em um orfanato, deu-me material (livros, vitrola, discos, brinquedos) e principalmente, deu-me crédito e apoio.

Fui ao orfanato.

\footnotetext{
- Estudante do Curso de Graduação em Enfermagem e Obstetrícia da Escola de Enfermagem da USP.
} 
Muitas crianças, poucas pagens, narizes sujos, pouco espaço, gritaria, brigas,... Tive vontade de voltar, esquecer. Será que poderei aprender ou fazer alguma coisa aqui? pensei.

- Ochê é minha māe? Voltei à realidade; um garotinho preto segurava-me pela mão e olhava ansiosamente nos meus olhos. Deveria ter 4 ou 5 anos. Como é possível um garoto desta idade fazer uma pergunta assim? O que é ser mãe para ele? Esse garoto deve estar muito confuso, concluí. Então respondi:

- Não, mas quero ser sua amiga.

Estava rodeada de crianças querendo tocar-me; empurravam-se, acotovelavam-se, estendiam os bracinhos na minha direção. Nunca me havia sentido tão querida e necessária. Assim, aquelas crianças, em nosso primeiro encontro, deram-me algo que eu precisava: deram-me amor.

Resolvi voltar outras vezes.

- Que bom ! Ochê voltou. Havia um sorriso muito sincero naquele rostinho mulato, sujo e manchado de "merthiolate". Olhei bem para ele. Será que esta criança pode ser agressiva?

- Vamos brincar? perguntei.

Durante quase toda manhã, eu e as crianças corremos, dramatizamos, contamos histórias. De repente, um menino começou a agredir-me com socos e pontapés.

- Por que você está fazendo isso? indaguei.

- Porque... ochê num corre comigo.

Isto eu nāo entendi, afinal haviamos corrido juntos.

- Eu gosto de você, vim aqui para brincarmos juntos, mas você não pode bater em mim, expliquei. Ele parou.

Será que ele me agrediu para ser acolhido ou estava testando meus sentimentos? Será que estava experimentando se de fato eu poderia aceitá-lo como ele é? Talvez, também, ele tivesse medo de fazer amizade e ter que enfrentar novamente a experiência da separação.

Cena parecida iria reperti-se.

- Eu não gosto de você ! gritou um loirinho no outro dia.

- Você não gosta de mim.

- Por que você não gosta de mim?

- Por causa do seu “kichut". Respondeu, depois de pensar um pouco.

Tentei brincar com ele, mas mantendo uma certa distância para lhe mostrar que respeitava o seu direito de não gostar de mim. Aos 
poucos, ele foi se aproximando e não demorou muito para que estivesse em meus braços, beijando-me. $\mathrm{Na}$ hora de nos despedirmos, ele disse:

\section{- Pode vir com o seu "kichut" amanhã, tá?}

Aprendi muito nesse orfanato. Pude verificar que essas crianças têm realmente um atraso no desenvolvimento motor, têm atraso maior na linguagem, muitas urinam na cama, são desconfiadas, etc... Mas, aprendi, também que, apesar de todos esses problemas, elas têm muito amor para dar e têm necessidade de alguém para amar, alguém que esteja disposto a receber um abraço e um beijo. Este é um comportamento que precisa ser reforçado. BROIDE ${ }^{7}$ afirma que, com o passar dos anos, a criança não será amorosa, não pelo fato de não ter recebido amor, mas porque quando tinha amor para dar, não havia quem o recebesse. Trata-se de um comportamento nato da criança, que por não ser reforçado desapareceu.

MASLOW" faz notar que as emoções anti-sociais - a hostilidade, a inveja - resultam da frustração dos impulsos mais profundos do amor, da segurança e da posse, que são em si mesmos desejáveis.

MONTAGU * sustenta a tese de que a cooperação, mais do que a luta, é a lei fundamental da vida humana.

ROGERS ${ }^{5}$ afirma que o centro mais intimo da natureza humana, as camadas mais profundas da personalidade, a base da "natureza animal", tudo isso é naturalmente positivo, fundamentalmente socializado, dirigido para diante, racional e realista.

Fato semelhante podemos ver mais facilmente com relação à linguagem.

Segundo SANDSTRÖM ${ }^{6}$, os sons não são aprendidos. Dois meses depois do nascimento, a criança tem à sua disposição todos os sons lingüísticos que a voz humana pode reproduzir, mas os sons que não são reforçados pelo ambiente, desaparecem. E um fato comprovado que as crianças surdas não balbuciam. Isto é uma prova de que um estímulo para fala promanado do meio ambiente, é do mais alto significado mesmo na fase do balbucio. O pensamento é impossível sem a linguagem, e a acuidade, a lucidez do pensamento, estão intimamente relacionados com a construção lógica de frases.

GESELL ${ }^{2}$ afirma que um meio lingüistico defeituoso tem efeito cumulativamente aviltante e depauperante no desenvolvimento intelectual. Tudo isso acontece quando não reforçamos os sons emitidos por um bebê.

O que acontecerá se não reforçarmos a demonstração de amor de uma criança? Creio que essa resposta nós já sabemos, pois temos sentido em nossa vida diária os problemas de uma sociedade, onde há falta de confiança, de respeito e de amor. 
Muitas coisas aquelas criancinhas me ensinaram, porem o que mais me marcou foi o fato de que se estivermos dispostos a receber todo o amor que os órfãos, assim como tantas crianças, têm para nos dar, estaremos contribuindo para a formação de um mundo melhor.

SANTOS, M. L. de M. e What I learned interacting with orphan children. Rev. Esc. Enf. USP, São Paulo, 16(1):103-106, 1982.

The Author reports her experience with orphan children during her field work in an orphange as a nursing student, emphasizing some significant aspects for her learning. She concludes that there must be someone willing to receive all the love the orphan children have to give.

\section{REFERENCIAS BIBLIOGRAFICAS}

1 - FRAIBERG, S. H. Os anos mázicos. Rio de Janeiro, Bloch, 1972.292 b.

2 - GESELL, A. apud SANDSTROM, C. I. A psicologia da infância e da adolescência. 3 . ed. Rio de Janelro, Zahar, 1971. p.131.

3 - MASLOW, A. H. apud ROGERS, C. R. Tornar-se pessoa. 3. ed. São Paulo, Martins Fontes, 1978. p.92.

4 - MONTAgU, A. apud ROgers, C. R. Tornar-se pessoa. 3. ed. São Paulo, Martins Fontes, 1978. p.92.

5 - ROGERS, C. R. Tornar-se pessoa. 3. ed. São Paulo, Martins Fontes, 1978. p.259.

6 - SANDSTROM, C. I. Desenvolvimento da linguagent e do pensamento. In:

A psicologia da infância e da adolescência. 3. ed. Rio de Janeiro. Zahar, 1971. p.125-6.

7 - BRoIde, J. Vem. Vem sem Febem, vem. Psicologia atual, Săo Paulo, 2(10):17-8, s.d. 